\section{Firmness and Drained Weight of Fruit of 19 Strawberry Clones}

\author{
Patrick P. Moore \\ Washington State University, Puyallup, Research and Extension Center, 7612 \\ Pioneer Way E, Puyallup, WA 98371-4998
}

Additional index words. Fragaria $\times$ ananassa, cultivar, correlation

\begin{abstract}
Plots of 19 clones of strawberry (Fragaria Xananassa Duch.) were planted in 1996. Fruit of 16 clones were harvested in 1997 and fruit of 11 of the same clones plus three additional clones in 1998 . Individual plots were harvested on three or four dates in 1997 and from three to seven dates in 1998. Fruit firmness was determined with a penetrometer at harvest, and additional samples were processed and frozen for subsequent determination of percentage of drained weight. Clones differed in firmness in both years and in drained weight in 1998, but not in 1997. Drained weight varied considerably from harvest-to-harvest. Correlations between firmness and drained weight were significant $(P \leq 0.01)$ in both years, but firmness was not a good predictor of drained weight. The correlation between drained weight of fruits in 1997 and those of fruits from the same plots in 1998 was nonsignificant, but that between firmness in 1997 and firmness in 1998 was significant at $P \leq 0.05$.
\end{abstract}

Over $90 \%$ of strawberry fruit produced in Oregon and Washington was sold for the processing market in 1997 and 1998 (Washington Agricultural Statistics Service, 1999). A cultivar that produces high quality fresh fruit may not produce high quality fruit for a frozen or processed product (Schrader and Scott, 1947; Sistrunk and Moore, 1971). Evaluation procedures in a breeding program must be suited to the end product of the crop.

Penetrometric methods of assessing fruit firmness are commonly used by many strawberry breeding programs. Hietaranta and Linna (1999) found that the maximum force for a probe to reach a depth of $6 \mathrm{~mm}$ was consistent with sensory evaluations of fruit firmness of fresh fruit. Sistrunk and Moore (1967) found that resistance to shear, drained weight, viscosity, and percentage of mushy slices were tests that "defined differences in character and wholeness" of thawed frozen strawberries. Although penetrometric methods may be satisfactory for evaluating material for fresh fruit quality, they may not be satisfactory for evaluating material for processing uses. For example, 'Puget Beauty' was reported to have firmer fresh fruit than 'Marshall', but frozen fruit of 'Marshall' had higher shear-press measurements than did those of 'Puget Beauty' (Sistrunk et al., 1960).

Drained weight is the percentage of a sample that remains on a sieve after draining for a given period of time. It is a measure of fruit integrity and is used by some fruit purchasers as one of the criteria to determine if strawberry fruit are acceptable. Measurement of fruit firmness using

Received for publication 15 Nov. 1999. Accepted for publication 2 June 2000. H/LA Paper no. 99-2. Washington State Univ., College of Agriculture and Home Economics, Pullman Project no. 0038. The cost of publishing this paper was defrayed in part by the payment of page charges. Under postal regulations, this paper therefore must be hereby marked advertisement solely to indicate this fact. penetrometric methods is simpler than preparing samples for drained weight determination. The objective of this study was to determine if firmness of fresh strawberry fruit, measured with a penetrometer, predicted the drained weight of samples from the same harvests.

\section{Materials and Methods}

Three, 3.1-m plots for each clone, grown as matted rows, were established in 1996 at Washington State Univ., Puyallup, Wash. (WSU Puyallup), in a randomized block planting. Fruit of 16 clones were evaluated in 1997 and 11 of these clones plus three additional clones were evaluated in 1998. In both years, two or three plots for each clone were harvested weekly.

Firmness (the force required for a $4 \mathrm{~mm}$ diameter cylinder to penetrate the shoulder of whole fruit to the depth of $6 \mathrm{~mm}$ ) was measured in Newtons (N) using a Hunter Spring Mechanical Force Gauge (Series L; Ametek, Hatfield, Pa.) for five fruit per plot at each harvest. Samples were collected for each harvest for drained weight determination. Fruit were washed, drained, and sliced in half. Sugar (Fred Meyer, Portland, Ore.) was added at the rate of 1 sugar : 4 fruit (by weight). The fruit and sugar were placed in metal bowls and mixed quickly with a spoon to partially dissolve the sugar. The samples were put in containers (Rubbermaid No. 3870 Servin'Saver ${ }^{\circledR}$ Sandwich Keeper, 1pint; Rubbermaid, Wooster, Ohio) and frozen at $-20^{\circ} \mathrm{C}$. The sugared samples averaged 400 g. After 4 to 5 months, samples were thawed overnight at room temperature $\left(\approx 18{ }^{\circ} \mathrm{C}\right)$. Samples were placed on a No. 8 sieve for $2 \mathrm{~min}$ and the material remaining on the sieve weighed. The drained weight was calculated as the weight of sample remaining on the sieve divided by the total weight.

In 1997, there were five harvests with individual plots being harvested on three or four dates (161 total samples). In 1998, there were seven harvests with individual plots being harvested on three to seven dates (154 total samples). Seasonal weighted averages for each year were calculated for firmness and drained weight for each plot. Data were analyzed as a randomized block design using SAS GLM (SAS Institute, 1996) with means separated using Tukey's Studentized range test (HSD), $P \leq 0.05$.

Twenty-two plots were harvested on 11,18 , and 24 June and 1 July 1997. In 1998, 22 plots were harvested on 15, 22, and 29 June and 6 July. These data subsets were used to compare harvest date differences for drained weight and firmness. Data were analyzed by analysis of variance (ANOVA) for each year separately, with plot and harvest date as main factors and means for harvest dates separated using Duncan's multiple range test, $P \leq 0.05$ (SAS Inst., 1996). Weather data (total solar radiation; minimum, maximum, and average air temperature; average wind speed; total precipitation; duration of leaf wetness; Penman evapotraspiration (alfalfa); soil moisture and temperature at $20.3 \mathrm{~cm}$ ) for the day of harvest and the day before harvest at WSU Puyallup were obtained from the Public Agricultural Weather System (1999). Correlation coefficients were calculated between the weather data and the average drained weight for each harvest date.

Samples of 11 clones were collected from two plots in both 1997 and 1998. This subset of the data was analyzed separately by ANOVA and year, clone, and year $\times$ clone effects tested (SAS Institute, 1996).

\section{Results and Discussion}

Firmness. In both years, WSU 2253, 'Redcrest', and 'Independence' had firmness values > 2.0 N and ORUS 1267-236, 'Nanaimo' and WSU 2319 had values <1.7 N (Table 1). There were differences among the 11 clones measured in both 1997 and $1998(P \leq 0.0001)$, but year and clone $\times$ year interaction were nonsignificant at $P \leq 0.05$. The firmness measurements in the 2 years were significantly correlated $(r=0.59, \mathrm{n}=22, P \leq 0.01)$.

Drained weight. Clones differed for drained weight in 1998, but not in 1997 (Table 1). There were differences between years for drained weight for these 11 clones $(P \leq 0.0001)$, but clone and clone $\times$ year interaction were nonsignificant at $P \leq 0.05$. Drained weight measurements in the 2 years were not significantly correlated $(r=-0.28, \mathrm{n}=22$, N.S.).

Differences between years in drained weight could be a result of: 1) changes in fruit characteristics between the first and second fruiting season; or 2) weather differences. The most obvious change was a decrease in fruit weight from $13.3 \mathrm{~g}$ in 1997 to $10.4 \mathrm{~g}$ in 1998. Changes in fruit size could change the relative proportions of tissues affecting drained weight; however, the average fruit weight was not significantly correlated with drained weight or firmness in either year. The weather was more consistently wet during the harvest season in 1997 than in 1998. In June 1997, $4.8 \mathrm{~cm}$ of measurable precipitation fell in $13 \mathrm{~d}$. In June 1998, measurable precipitation totaled only 
Table 1. Firmness and drained weight of fruit of strawberry clones in 1997 and 1998. All plots planted in 1996.

\begin{tabular}{|c|c|c|c|c|}
\hline \multirow[b]{2}{*}{ Clone } & \multicolumn{2}{|c|}{1997} & \multicolumn{2}{|c|}{1998} \\
\hline & $\begin{array}{c}\text { Drained }^{\mathrm{z}} \\
\text { wt }(\%)\end{array}$ & $\begin{array}{c}\text { Firmness }^{\mathrm{z}} \\
(\mathrm{N})\end{array}$ & $\begin{array}{l}\text { Drained } \\
\text { wt }(\%)\end{array}$ & $\begin{array}{c}\text { Firmness } \\
(\mathrm{N})\end{array}$ \\
\hline$\overline{\text { Hood }}$ & $63.2 \mathrm{a}$ & $1.91 \mathrm{~cd}^{y}$ & $\begin{array}{ll}-- \\
\text { - }\end{array}$ & $\begin{array}{ll}-- \\
\end{array}$ \\
\hline Independence & $68.4 \mathrm{a}$ & $2.07 \mathrm{a}-\mathrm{c}$ & $68.8 \mathrm{~b}$ & $2.13 \mathrm{a}-\mathrm{d}$ \\
\hline Nanaimo & $64.7 \mathrm{a}$ & $1.65 \mathrm{de}$ & $69.3 \mathrm{ab}$ & $1.63 \mathrm{c}-\mathrm{e}$ \\
\hline ORUS 1267-236 & $66.2 \mathrm{a}$ & $1.64 \mathrm{de}$ & $69.6 \mathrm{ab}$ & $1.55 \mathrm{e}$ \\
\hline Puget Summer & $65.3 \mathrm{a}$ & $1.95 \mathrm{~cd}$ & $68.8 \mathrm{ab}$ & $1.54 \mathrm{c}-\mathrm{e}$ \\
\hline Redcrest & $66.5 \mathrm{a}$ & $2.24 \mathrm{ab}$ & $71.4 \mathrm{ab}$ & $2.59 \mathrm{a}$ \\
\hline Sumas & $63.6 \mathrm{a}$ & $1.73 \mathrm{c}-\mathrm{e}$ & $73.2 \mathrm{a}$ & $1.53 \mathrm{de}$ \\
\hline Totem & $66.0 \mathrm{a}$ & $1.82 \mathrm{c}-\mathrm{e}$ & $68.6 \mathrm{~b}$ & $1.87 \mathrm{~b}-\mathrm{e}$ \\
\hline WSU 2247 & --- & --- & $68.1 \mathrm{~b}$ & $1.92 \mathrm{~b}-\mathrm{e}$ \\
\hline WSU 2253 & $64.5 \mathrm{a}$ & $2.39 \mathrm{a}$ & $69.5 \mathrm{ab}$ & $2.34 \mathrm{ab}$ \\
\hline WSU 2288 & --- & --- & $71.2 \mathrm{ab}$ & $2.24 \mathrm{a}-\mathrm{c}$ \\
\hline WSU 2299 & $65.8 \mathrm{a}$ & $1.85 \mathrm{c}-\mathrm{e}$ & --- & --- \\
\hline WSU 2308 & $65.3 \mathrm{a}$ & $1.72 \mathrm{de}$ & $67.5 \mathrm{~b}$ & $1.93 \mathrm{a}-\mathrm{e}$ \\
\hline WSU 2315 & $65.7 \mathrm{a}$ & $1.86 \mathrm{c}-\mathrm{e}$ & $69.4 \mathrm{ab}$ & $1.92 \mathrm{a}-\mathrm{e}$ \\
\hline WSU 2317 & $64.0 \mathrm{a}$ & $1.83 \mathrm{c}-\mathrm{e}$ & --- & --- \\
\hline WSU 2319 & $63.8 \mathrm{a}$ & $1.65 \mathrm{de}$ & --- & --- \\
\hline WSU 2323 & --- & --- & $67.8 \mathrm{~b}$ & $1.92 \mathrm{~b}-\mathrm{e}$ \\
\hline WSU 2325 & $64.0 \mathrm{a}$ & $1.74 \mathrm{c}-\mathrm{e}$ & $69.0 \mathrm{ab}$ & $1.61 \mathrm{c}-\mathrm{e}$ \\
\hline WSU 2326 & $65.1 \mathrm{a}$ & $1.60 \mathrm{e}$ & --- & --- \\
\hline Mean & 65.1 & 1.85 & 69.4 & 1.91 \\
\hline
\end{tabular}

${ }^{2}$ Values represent weighted means for each harvest season for two or three 3.1-m plots.

yean separation within columns by Tukey's Studentized range test (HSD), $P \leq 0.05$

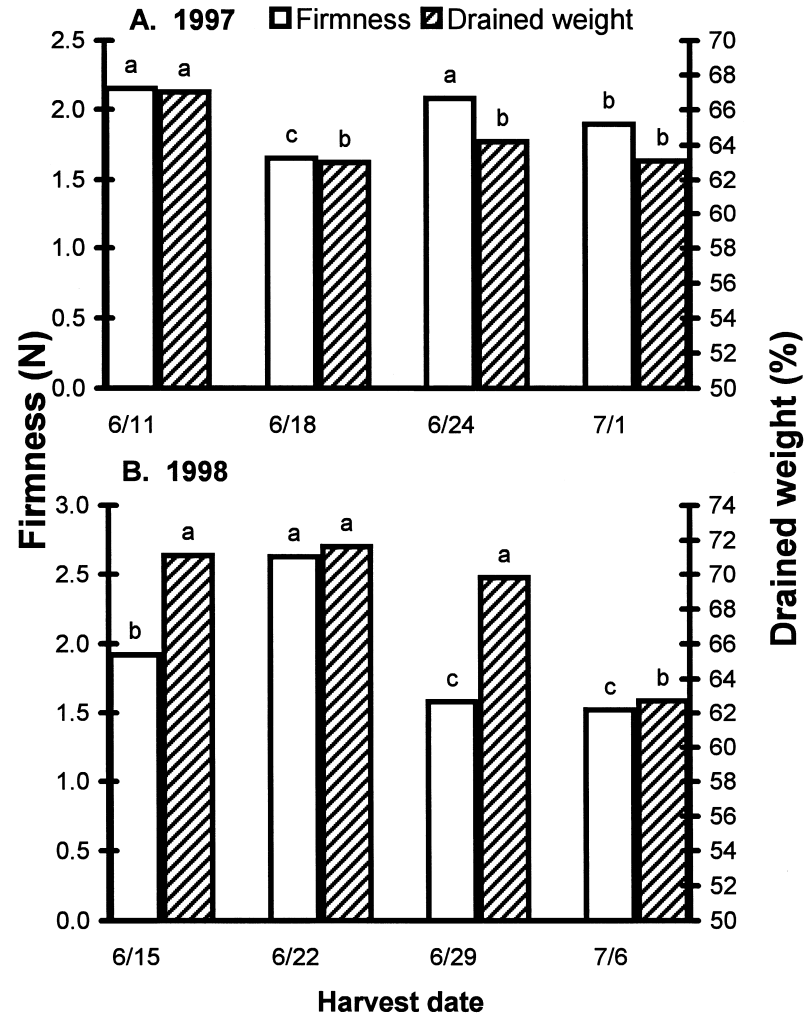

Fig. 1. Firmness and drained weight of strawberry fruit harvested on four dates during the harvest season. Letters indicate mean separation by Duncan's multiple range test, $P \leq 0.05$ for each variable.
$1.85 \mathrm{~cm}$ over $7 \mathrm{~d}$. The drier weather could have increased drained weight.

Drained weight fluctuated over the course of the season each year (Fig. 1). Only plots harvested on all four dates were included in the analysis, so differences are not a result of different clones being harvested on different dates. Similarly, firmness varied among harvests without following any seasonal trends (Fig. 1). Differences in drained weight and firmness over the course of the harvest season have been reported previously (Sistrunk, 1963; Sistrunk and Moore, 1967, 1971). In 1997, drained weight was positively correlated $(P \leq 0.05)$ with the duration of leaf wetness the day of harvest and with solar radiation and evapotranspiration the day before harvest, but was not significantly correlated with the other weather variables. In 1998, drained weight did not differ among the first three harvests. On 2 July, the plots received $2 \mathrm{~cm}$ of irrigation and fruit from the 6 July harvest had much lower drained weights. The drained weight on 29 June averaged $69.8 \%$ and decreased to $62.7 \%$ on 6 July, yet the firmness did not change (Fig. 1). The decrease in drained weight $(7.1 \%)$ was larger than the largest difference between clones $(5.7 \%)$. From the impact of the irrigation and the correlations with weather data, drained weight appears to be very sensitive to weather conditions, especially those that affect the plant's moisture status. The impact of weather and irrigation on fruit quality is consistent with Kimbrough's (1930) findings of fruit being higher in moisture after rainy periods and fruit from irrigated plots being softer than those from nonirrigated plots.
The correlation coefficient between drained weight and firmness, using all samples, was $0.27(\mathrm{n}=161, P \leq 0.01)$ in 1997 and $0.42(\mathrm{n}=$ $154, P \leq 0.01)$ in 1998 . When weighted seasonal means for each clone were used, the correlation coefficient was $0.28(n=16$, N.S. $)$ in 1997 and $0.11(\mathrm{n}=14$, N.S.) in 1998 . Although drained weight and firmness were significantly correlated when all samples were included as individual data points, fruit firmness was a poor predictor of drained weight. While some clones, e.g., 'Redcrest', were firm and had high drained weight, there were exceptions. WSU 2253 was very firm, but had average drained weight. In 1998, 'Sumas' had the softest fruit, but the greatest drained weight. Its high drained weight may partially be a consequence of ripening date. 'Sumas' is an early-ripening clone and most of its fruit was harvested on dates that had high drained weights in 1998 (Fig. 1).

The large variation in drained weight among harvest dates and between years suggests that many sampling dates over several years may be necessary to accurately assess the drained weight of a clone. Although a penetrometer can be used to evaluate the firmness of fresh fruit, these values cannot be used to satisfactorily predict the drained weight of sliced, sugared, frozen strawberries. Firmness and drained weight were significantly correlated using observations from each harvest of each plot, but value of $r^{2}$ was $<0.20$. When weighted means for the season were calculated for each clone, the $r^{2}$ values between firmness and drained weight were
$<0.10$ and nonsignificant. This indicates that, if the objective of a breeding program is to develop new cultivars for processing, drained weight needs to be measured rather than firmness of fresh fruit.

\section{Literature Cited}

Hietaranta, T. and M. Linna. 1999. Penetrometric measurement of strawberry fruit firmness: Device testing. HortTechnology. 9:103-105.

Kimbrough, W. 1930. The quality of strawberries as influenced by rainfall, soil moisture and fertilizer treatments. Proc. Amer. Soc. Hort. Sci. 27:184-186.

Public Agricultural Weather System. 1999. http:// frost.prosser.wsu.edu.

SAS Institute, Inc. 1996. The SAS system for windows. Release 6.12. SAS Inst., Cary, N.C.

Schrader, A.L. and D.H. Scott. 1947. Quality comparisons of strawberry varieties as affected by processing with the freezing method. Proc. Amer. Soc. Hort. Sci. 50:246-250.

Sistrunk, W. A. 1963. Field conditions and processing practices relating to frozen strawberry quality. Proc. Amer. Soc. Hort. Sci. 83:440-446.

Sistrunk, W.A., R.F. Cain, E.K. Vaughan, and H.B. Lagerstedt. 1960. Factors contributing to the breakdown of frozen sliced strawberries. Food Technol. 14:640-644.

Sistrunk, W.A. and J.N. Moore. 1967. Assessment of strawberry quality-Fresh and frozen. Food. Technol. 21:131A-135A.

Sistrunk, W.A. and J.N. Moore. 1971. Strawberry quality studies in relation to new variety development. Arkansas Agri. Expt. Sta. Bull., 761.

Washington Agricultural Statistics. 1999. Washington 1998 Berry Rpt., 21 Jan. 1999. http:// www.nass.usda.gov/wa/berryrpt.htm. 